\title{
Individual Student Planning: A Comparison Between United States and Indonesia
}

\author{
C.P. Bhakti \& A.R. Kumara ${ }^{a}$, B. Astuti \& Suwarjo \\ ${ }^{a}$ Universitas Ahmad Dahlan, Yogyakarta, Indonesia \\ ${ }^{\mathrm{b}}$ Universitas Negeri Yogyakarta, Yogyakarta, Indonesia
}

\begin{abstract}
This article presents a comparison of individual student planning between United States and Indonesia, providing history and development of individual student planning, issues and trends of individual student planning, individual student planning strategies, and the implementation of individual student planning strategies between the two countries. Writing method used is literature study. Qualitative and quantitative. Source of data and information obtained from various literatures. The results of the study show that the individual model of student planning in America has been ideal. While in Indonesia, it structures individual model of student planning. Implementation in Indonesia, at the policy level is good, but need more operational development in the implementation of individual student planning at elementary level, high school, and vocational school.
\end{abstract}

Keywords - Individual Planning; Comparison; Unied States; Indonesia

\section{INTRODUCTION}

The student's specialization service is a guiding area of the guidance and counseling profession, which is covered by individual student planning services (Permendibud no 111 2014: 9). Individual planning service activities are not merely concentrated but, conceptually, Gysbers \& Henderson (2012: 88) explains that individual planning services are systematic activities designed to help learners understand and take action to develop future plans [2]. The strategy of implementation services can be in both group and individual formats. The undertaken activities include the recognition of personal character, measuring the level of achievement of his goals, and taking decisions that reflect his self-planning.

Development of the implementation of specialization services has been conducted several studies. Zamroni's research (2014) develops effective interactive multimedia to enhance the skills of making career decisions in the junior high school program [14]. Another study by Makrifah (2014) develops a specialization package in classical counseling services for students in junior high [9]. Research Marlina, et al (2015) has developed Career Career Inventory as a means of measuring student career planning direction [10]. Kursi Research (2016) result shows the positive effect of the implementation of Study Program Selection information the consistency of high school choice made by the students of SMPN 2 Maros [8].

Individual student planning is part of a comprehensive counseling and counseling program [13]. In Indonesia the implementation of comprehensive guidance and counseling pro- grams is clearly recognized in the regulation of Permendikbud No 27/2008 on Academic Competency Standards and Counselor Qualifications. Government regulation on the 2013 curriculum focusing on specialization services. In the development of individual student planning services in Indonesia, comparative studies should be conducted in countries that have undertaken individual student planning in advance such as in the United States. This comparative study is important to design a more comprehensive, individualized student planning design in Indonesia

\section{METHOD}

Writing method used is literature study. Qualitative and quantitative. Sources of data and information obtained from various literatures and compiled based on the results of studies of information obtained. Writing is strived to be mutually related to each other and in accordance with the topic being studied. The collected data is selected and sorted according to the topic of the study.

\section{RESULT AND DISCUSSION}

Guidance and counseling born in America, as the development of individual model planning adopted in various countries one of them is Indonesia. The description of individual model of student planning in America is summarized in the table below.

TABLE I. INDIVIDUAL STUDENT PLANNING IN US

\begin{tabular}{|c|c|}
\hline Aspect & $\mathbf{U S}$ \\
\hline Purpose & Development and use of Personal Plans of Study \\
\hline Topic & $\begin{array}{l}\text { 1. Course Selection } \\
\text { 2. Transitioning grade to grade, school to school, } \\
\quad \text { school to career } \\
\text { 3. Multiple year planning } \\
\text { 4. Financial Aid } \\
\text { 5. Knowledge of career opportunities } \\
\text { 6. Career Awareness } \\
\text { 7. Interest inventotries } \\
\text { 8. Career Shadowing } \\
\text { 9. Work Habits } \\
\text { 10. Setting Personel Goals } \\
\text { 11. Decision making skill }\end{array}$ \\
\hline Primary Focus & $\begin{array}{l}\text { There is a standard focus on individual student plan- } \\
\text { ning achievement from K- } 3 \text { to K- } 12 \text { level }\end{array}$ \\
\hline Counselor Role & $\begin{array}{l}\text { 1. Appraisal } \\
\text { 2. Education and career planning }\end{array}$ \\
\hline
\end{tabular}




\begin{tabular}{|c|l|}
\hline Aspect & \multicolumn{1}{|c|}{ US } \\
\hline & $\begin{array}{l}\text { 3. Transitions } \\
\text { 4. Schoolwide workshops for teacher, student and } \\
\text { families }\end{array}$ \\
\hline
\end{tabular}

The effectiveness of successful implementation of individual student planning in US has been proven in several related research reports. Breaking Ranks in the Middle (NASSP, 2006) also emphasized individual student planning. The report recommended that the sixth or seventh graders and their parents be introduced to planning for their education and beyond. The report stressed the need for students to meet frequently and meaningfully with an adult to plan and review their development. Stressed the importance of individual career plans for student. They examined the course of study as a result of the development of individual career plans. They also described a number of implementation issues, including the challenges involved in the implementation process.

The development of individualized student planning services in Indonesia needs to be comprehensively designed. Regulation and a set of support implementation of specialization already exist, but need to be developed better. Specialization activities are not only implemented at secondary school level, but need to be prepared early on. It is necessary to develop a focus design of individual planning service activities as well as the achievement of each level of education from primary to secondary school.

In general, the description of individual model of student planning in Indonesia is summarized in the table 2.

TABLE II. INDIVIDUAL STUDENT PLANNING IN INDONESIA

\begin{tabular}{|c|c|}
\hline Aspect & Indonesia \\
\hline Purpose & $\begin{array}{l}\text { 1. self-understanding and the environment, } \\
\text { 2. able to formulate goals, planning, or management of his } \\
\text { own development, whether involving personal aspects, } \\
\text { social, learning, and career, and } \\
\text { 3. able to formulate goals, planning, or management of their } \\
\text { own development, whether involving personal, social, } \\
\text { learning, and career aspects; } \\
\text { 4. can perform activities based on the understanding, goals, } \\
\text { and plans that have been formulated }\end{array}$ \\
\hline Topic & $\begin{array}{l}\text { 1. Self-understanding } \\
\text { 2. positive self-concept } \\
\text { 3. understanding the environment } \\
\text { 4. development of effective social skills, } \\
\text { 5. efficiency and effectiveness of learning, } \\
\text { 6. learning skills, } \\
\text { 7. the interests of learners / counselee appropriately, } \\
\text { 8. career opportunities, } \\
\text { 9. explore work practices, } \\
\text { 10. the need for positive work habits }\end{array}$ \\
\hline $\begin{array}{ll}\text { Primary } & \text { Fo- } \\
\text { cus } & \end{array}$ & $\begin{array}{l}\text { There is no focus of achievement Individual Student Plan- } \\
\text { ning from elementary, junior high school, senior high } \\
\text { school, vocational high school }\end{array}$ \\
\hline $\begin{array}{l}\text { Counselor } \\
\text { Role }\end{array}$ & $\begin{array}{l}\text { 1. the provision of in-depth program information } \\
\text { 2. do the mapping and determination of the interest of } \\
\text { learners (data collection, data analysis, interpretation of } \\
\text { the results of data analysis and determination of the } \\
\text { interest of learners); } \\
\text { 3. cross-interest services; } \\
\text { 4. an interest-deepening service; } \\
\text { 5. the service moved interest; }\end{array}$ \\
\hline
\end{tabular}

\begin{tabular}{|l|l|}
\hline Aspect & \multicolumn{1}{|c|}{ Indonesia } \\
\hline & $\begin{array}{l}\text { 6. mentoring is done through classical guidance, group } \\
\text { guidance, individual counseling, group counseling, and }\end{array}$ \\
& consultation, \\
& 7. development of distribution; \\
8. evaluation and follow-up.
\end{tabular}

The foundations for individual student planning is established during the elementary school years through guided curriculum activities, self-concept development, the acquisition of learning to learn skills, interpersonal relationships skill development, decision making skill building, and awareness and beginning of exploration of educational and occupational possibilities. Then it continues to be converted through the guiding curriculum in middle school and high school, providing new information and experience to enable students to regularly update, monitor, and managing their plans effectively.

Guidance and counseling teachers assist in the process of stabilizing students' interests that have been selected and determined. In counseling scope, teacher guide and give a counseling in cooperation with the classroom teachers and parents. An assistance can be done individually, in group and classically. Mentoring is very important to help learners make adjustments to the specialization in the subject groups, cross-subject specialization and deepening specialization subjects that have been set.

Individual student planning activities are not only limited assistance in the establishment of the study, but the teacher guidance and counseling provide life skills such as orientation to school, time management, self-assessment, communication, decision making, relationships, career development, and education planning. These skills are packed in various ways such as classical guidance, group counseling, individual counseling and consultation.

Individual student planning is a part of comprehensive guiding and counseling program. The implementation of individual student planning in accordance with applicable regulations can be implemented properly if only it is supported by intact competencies in guidance and counseling teachers. The implementation of guidance and counseling programs requires conceptual mastery of qualified intact and skill. According to the implementation of comprehensive counseling program that is completely consistent with developmental theory requires a truly trained counselor who masters the theory of development. In addition to strengthening the knowledge side, guidance and counseling teachers need to be equipped with a comprehensive set of training in implementing comprehensive guidance and counseling programs. This view is in line with the results of research that the practice training of comprehensive guidance and counseling programs is effective in improving the implementation of counseling and guidance programs at high schools in Winconsin, America. 


\section{CONCLUSIONS}

Guidance and counseling were born in America which gradually spread to Indonesia. Individual student planning is part of a comprehensive guidance and counseling program. Implementation of individual student planning is not only limited to clear regulation support, but it is also necessary to develop the focus of individual student planning and achievement in each level of education. The success of individual student planning implementation is supported by complete competence.

\section{REFERENCES}

[1] A. Burkard, M. Gillen, M. Martinez, \& S. Skytte, "Implementation challenges and training needs for comprehensive school counseling programs in Wisconsin high schools," Journal of Professional School Counseling, vol. 16, no. 2, pp. 136-145, 2012.

[2] N.C. Gysbers, \& P. Henderson, Developing and Managing Your School Guidance and Counseling Program FIFTH Edition, American Counseling Assosiation, Alexandria. 2012.

[3] N.C. Gysbers, \& E.J. Moore, Improving guidance programs. Prentice Hall, Englewood Cliffs, NJ. 1981.

[4] N.C. Gysbers, Competency-based career guidance modules: Category C: Implementing: Create and use an individual career development plan. 1985.

[5] Juntika, Membangun Peradaban Bangsa Indonesia Melalui Pendidikan dan Komprehensif Bernutu, Pidato Pengukuhan Prof. Dr. H. Juntika, M.Pd sebagai Guru Besar/Profesor dalam Bidang Bimbingan dan Konseling Pada Fakultas Ilmu Pendidikan Universitas Pendidikan Indonesia, 15. 2011.

[6] S. Kalchik, \& K.M. Oertle, The relationship of individual career plans to programs of study and career pathways. Transition Highlights, 3. 2011.

[7] Kebudayaan, Kementerian Pendidikan dan Kebudayaan Direktorat Jenderal Guru dan Tenaga Kependidikan, "Panduan Operasional Penyelenggaraan Bimbingan Dan Konseling."

[8] A.M. Kursi, "Pengaruh Layanan Informasi Peminatan Terhadap Kemantapan Pilihan Sekolah Lanjutan Siswa Smpn 2 Maros," Jurnal Psikologi Pendidikan Dan Konseling, vol. 2, no. 1, pp. 49-57, 2016.

[9] F.L. Makrifah, \& W. Nuryono, "Pengembangan Paket Peminatan Dalam Layanan Bimbingan Klasikal Untuk Siswa Di SMP," Jurnal BK, vol. 4, no. 3, pp. 1-8, 2014.

[10] E. Marlina, M. Arifin Ahmad, \& A. Pandang, "Pengembangan Inventori Peminatan Karir (Ipk) Sebagai Alat Ukur Arah Pilih Karir Siswa," Jurnal Penelitian Tindakan Bimbingan \& Konseling, vol. 1, no. 1, 2015.

[11] Myrick, D. Robert, Developmental Guidance and Counseling : A Practical Approach Fifth edition, Educational Media Corporation, Minneapolis, 2011.

[12] Nebraska Department of Education, Nebraska Personal Learning Plans [Brochure], Retrieved November 29, 2008, http://www.nde.state.ne.us/ cared/documents/PLPBrochure.pdf. 2008.

[13] R. Thompson, Professional school counseling: Best practices for working in the schools. Routledge. 2012.

[14] E. Zamroni, D.Y.P. Sugiharto, \& I. Tadjri,'Pengembangan Multimedia Interaktif Bimbingan Karir Untuk Meningkatkan Keterampilan Membuat keputusan Karir Pada program Peminatan Siswa SMP," Jurnal Bimbingan Konseling, vol. 3, no. 2, 2014. 